\title{
Analisis Kelayakan Pengembangan Alat Evaluasi Kognitif Berbasis Android pada Program Studi Pendidikan TIK
}

\author{
Isnania Lestari*1, Sandrawati ${ }^{2}$ \\ ${ }^{1,2}$ Program Studi Pendidikan Teknologi Informasi dan Komputer, IKIP PGRI Pontianak \\ email: isnanialestari@gmail.com*11,sandrawati@gmail.com²
}

(Received: 30 Oktober 2021 / Accepted: 25 November 2021 / Published Online: 20 Desember 2021)

\begin{abstract}
Abstrak
Tahapan evaluasi merupakan tahap akhir dalam proses pembelajaran. Saat ini, proses evaluasi masih menggunakan cara manual. Berdasarkan hal tersebut, maka dikembangkan aplikasi sebagai alat evaluasi kognitif berbasis android pada Program Studi Pendidikan Teknologi Informasi dan Komputer (PTIK) IKIP PGRI Pontianak. Tujuan penelitian ini adalah untuk menganalisis kelayakan pengembangan alat evaluasi kognitif berbasis android dan juga Respon mahasiswa setelah menggunakan alat evaluasi kognitif berbasis android di Program Studi Pendidikan TIK IKIP PGRI Pontianak. Metode pengembangan yang digunakan adalah penelitian Research and Development (R\&D) dengan model ADDIE. Subjek penelitian dalam penelitian terdiri dari subjek pengembangan yang melibatkan 3 ahli media dan subjek ujicoba produk yang melibatkan 10 mahasiswa sebagai subjek uji coba skala kecil dan 42 mahasiswa sebagai subjek uji coba skala besar. Teknik pengumpulan data dengan menggunakan angket tertutup. Analisis data yang digunakan adalah analisis deskriptif kuantitatif. Hasil uji ahli media diperoleh skor 90,3\% termasuk kategori Sangat Layak. Ujicoba skala kecil diperoleh skor $76 \%$ dengan kategori Layak. Ujicoba skala besar diperoleh skor $81 \%$ dengan kategori Sangat Layak. Hasil respon yang diperoleh sangat baik, karena telah memenuhi aspek - aspek yang dibutuhkan dalam pembuatan aplikasi.
\end{abstract}

Kata kunci: Android, Aplikasi, Evaluasi, Kognitif.

\begin{abstract}
The evaluation stage is the final stage in the learning process. Currently, the evaluation process is still using the manual method. Based on this, an application was developed as an android-based cognitive evaluation tool at the Information and Computer Technology Education Study Program (PTIK) IKIP PGRI Pontianak. The purpose of this study was to analyze the feasibility of developing an android-based cognitive evaluation tool and also student responses after using an android-based cognitive evaluation tool in the ICT Education Study Program of IKIP PGRI Pontianak. The development method used is Research and Development $(R \& D)$ research with the ADDIE model. The research subjects in the study consisted of development subjects involving three media experts and product trial subjects involving 10 students as small-scale test subjects and 42 students as large-scale trial subjects. Data collection using closed questionnaires, and Data analysis apply descriptive quantitative analysis. The results of the media expert test obtained a score of $90.3 \%$, including the Very Eligible category. Small-scale trials obtained a score of $76 \%$ in the Eligible category. Largescale trials obtained a score of $81 \%$ in the Very Eligible category. The response results obtained are very good, because they have fulfilled the aspects needed in making the application.
\end{abstract}

Keywords: Android, Application, Evaluation, Cognitive.

\section{PENDAHULUAN}

Evaluasi pembelajaran merupakan bagian yang sangat penting dalam proses pembelajaran. Evaluasi bertujuan untuk mengukur tingkat pemahaman terhadap materi pembelajaran yang telah disampaikan. Evaluasi dilakukan di tahap akhir dari proses pembelajaran. Peran dari evaluasi ini sangat penting dalam proses pembelajaran. Seperti yang 
dijelaskan (Mahirah, 2017) bahwa manfaat utama dari evaluasi adalah meningkatkan kualitas pembelajaran dan selanjutnya akan terjadi peningkatan kualitas Pendidikan. Dalam tahapan ini dapat terlihat akurasi data dari kemampuan atau data kesulitan peserta didik dalam belajar. Dan data tersebut sangat tergantung dari alat dan proses evaluasi yang digunakan (Setemen, 2010). Data yang didapat dari evaluasi adalah berupa nilai atau angka yang menggambarkan tingkat kemampuan dan pemahaman dalam pembelajaran. Pada tahapan evaluasi ini terdapat beberapa aspek yang di nilai. Salah satunya adalah aspek kognitif. (Rahmayanti \& Wibowo, 2019) menjelaskan bahwa aspek kognitif digunakan untuk mengukur pemahaman materi yang telah diajarkan. Karena seperti yang dijelaskan oleh Mundilato dalam (Setyawardani et al., 2012) apabila teori kognitif ini digunakan sebagai dasar pijakan dalam mengembangkan pendekatan pembelajaran, maka aspek pemahaman merupakan inti dari proses belajar. Karena keberhasilan dalam proses Pendidikan, merupakan hal yang paling ingin di capai. Untuk mengevaluasi aspek kognitif ini, maka dibutuhkan alat yang tepat. (Nuriyah, 2014) menjelaskan bahwa Alat evaluasi dapat berupa tes, kuesioner, wawancara, dan observasi. Penilaian Alat ukur evaluasi kognitif biasanya berupa tes. Hal ini karena hasil akhir dari aspek kognitif adalah pengetahuan dan pemahaman. Aspek kognitif dapat diukur dengan 2 cara, yakni tes subyektif dan objektif (Nurbudiyani, 2013). Tes objektif berupa pilihan ganda, sedangkan subjektif berupa essay.

Perkembangan teknologi saat ini sudah merambah ke ranah pendidikan. Pemanfaatan teknologi dalam ranah Pendidikan bertujuan untuk membantu proses Pendidikan supaya pada pelaksanaanya dapat lebih mudah, menarik dan efisien. Hampir seluruh proses pembelajaran dapat melibatkan teknologi di dalamnya. Cholik (2017) mengatakan bahwa perkembangan teknologi, informasi dan komunikasi dapat diintegrasikan dalam proses pembelajaran. Salah satu pemanfaatan teknologi adalah digunakan sebagai alat evaluasi. Walter dalam (Olisca \& Achadiyah, 2014) menjelaskan bahwa evaluasi berbasis komputer telah menjadi standar dan menjadi semakin menarik di dunia Pendidikan. Selanjutnya Mei et al dalam (Daryanes \& Ririen, 2020) menjelaskan bahwa perubahan dalam praktik pendidikan dan pengembangan teknologi telah menyebabkan peningkatan penggunaan alat pembelajaran berbasis digital pada pendidikan tinggi. Pemanfaatan teknologi sebagai alat pembelajaran berbasis digital juga selalu mengalami perkembangan. Teknologi yang dimanfaatkan tidak hanya berbasis komputer, tetapi telah merambah kepada aplikasi smartphone. Hal ini dikarenakan perkembangan smartphone berlangsung sangat cepat.

Hampir semua lapisan masyarakat dari usia sekolah sampai dewasa telah memiliki smartphone masing-masing. Terdapat dua sistem operasi smartphone yang banyak digunakan oleh masyarakat, salah satunya adalah android. Menurut safaat dalam (Kuswanto \& Radiansah, 2018) android merupakan sistem operasi Mobile device berbasis linux yang mencakup sistem operasi, middleware, dan aplikasi. Selain itu Android merupakan system operasi open source, maka platform ini terbuka bagi para pengembang untuk membuat aplikasi mereka sendiri. Dengan mengembangkan aplikasi di smartphone sebagai salah satu media dalam proses pembelajaran, akan sangat membantu proses pembelajaram berjalan lebih baik dan menarik. (Putra et al., 2017) menjelaskan bahwa penggunaan aplikasi android dapat meningkatkan motivasi belajar siswa dan membuat pembelajaran menjadi lebih aktif dan menarik sehingga menumbuhkan kemauan belajar yang berdampak pada meningkatnya hasil belajar. Hal ini dapat terjadi karena aplikasi di android sangat mudah digunakan dan juga dapat dibuat semenarik mungkin.

Pelaksanaan evaluasi pembelajaran di Program Studi Pendidikan Teknologi Informasi dan Komputer (PTIK) IKIP PGRI Pontianak masih manual atau berbasis kertas. Evaluasi pembelajaran dengan menggunakan kertas memakan biaya karena dosen harus menggandakan soal sesuai dengan jumlah mahasiswa. Selain itu juga, jika tes dengan menggunakan kertas akan memerlukan waktu untuk memeriksa hasil jawaban dari setiap 
mahasiswa. (Setemen, 2010) menjelaskan, terdapat lima kelemahan dari evaluasi manual atau berbasis kertas, yakni evaluasi memerlukan waktu dan biaya yang cukup banyak untuk memproduksi soal. Kedua pemilihan butir tes dari bank soal cukup merepotkan, ketiga proses pemeriksaan evaluasi yang cukup rumit dan cenderung memakan banyak waktu dan membosankan. Keempat, pemberian skor dan pemberian umpan balik yang cukup rumit, dan terakhir evaluasi manual cenderung memberikan kecemasan terhadap peserta tes. Pelaksanaan evaluasi sebaiknya harus efektif dan efisien, mengingat hasil evaluasi pembelajaran merupakan hal yang penting. Karena dari hasil evaluasi ini terlihat kemampuan yang dimiliki oleh mahasiswa. Beberapa dosen di IKIP PGRI Pontianak telah mengembangkan beberapa media pembelajaran untuk digunakan dalam pembelajaran. Seperti yang di buat oleh (Matsun et al., 2018) yang mengembangkan bahan ajar berbasis android untuk membatu proses pembelajaran mahasiswa. Namun dalam media tersebut, belum adanya evaluasi pembelajaran sebagai tahap akhir penilaian materi yang telah diajarkan. Oleh sebab itu, maka dikembangkan aplikasi sebagai alat evaluasi kognitif.

Aplikasi ini di buat untuk melengkapi media pembelajaran yang telah di kembangkan oleh beberapa dosen. Selain itu, manfaat aplikasi ini untuk mempermudah proses dilakasanakannya proses evaluasi dalam pembelajaran. Dengan menggunakan aplikasi sebagai alat evaluasi, diharapkan dapat lebih mengefektifkan dan mengefisienkan waktu dan tenaga yang digunakan. Guardia, et al dalam (Daryanes \& Ririen, 2020) menjelaskan bahwa perlu adanya sistem evaluasi partisipatif yang dengan metode penilaian tingkat tinggi dan dapat menghasilan partisipasi siswa menjadi lebih besar sehingga siswa lebih berdaya dan dapat meningkatkan kualitas pendidikan. Salah satu bentuk pengembangan sistem evaluasi yang partisipatif ini adalah dengan mengembangkan aplikasi berbasi android sebagai alat evaluasi. Dengan menggunakan aplikasi, diharapkan proses evaluasi akan lebih mudah, murah dan juga efisien. Jenis tes yang digunakan dalam aplikasi ini adalah tes obyektif. Karena di sesuaikan dengan jenis tes yang digunakan oleh dosen saat pembelajaran. Tes obyektif digunakan karena dengan tes ini, soal yang digunakan bisa lebih banyak. Dengan menggunakan banyak soal, maka pengetahuan mahasiswa dapat di ukur dengan lebih baik. Aplikasi yang dikembangkan akan memberikan tampilan yang menarik sehingga mahasiswa lebih termotivasi dalam mengerjakan evaluasi pembelajaran. Fajriyyah \& Nugrahalia (2021) menjelaskan bahwa pelaksanaan evaluasi dengan menggunakan aplikasi dapat memudahkan peserta didik dalam memahami pembelajaran karena proses pembelajaran menjadi menarik dan menyenangkan. Tujuan dilakukannya pengembangan aplikasi ini adalah untuk mengetahui kelayakan pengembangan alat evaluasi kognitif berbasis android. Dan juga untuk mengetahui Respon mahasiswa setelah menggunakan pengembangan alat evaluasi kognitif berbasis android ini di Program Studi Pendidikan TIK IKIP PGRI Pontianak. Dengan aplikasi ini, diharapkan juga akan mempermudah dosen dalam melakukan perekapan nilai. Karena hasil evaluasi akan otomatis dihitung oleh aplikasi dan masuk kedalam database nilai mahasiswa. Selain itu, dengan menggunakan aplikasi, akan mengurangi biaya, karena dosen tidak harus menggandakan soal untuk mahasiswa.

\section{METODE}

Metode yang digunakan adalah Research and Development (R\&D) dengan model ADDIE. Model ini memiliki 5 tahap, yakni Analysis, Design, Development, Implementation, dan Evaluation. Model pengembangan ini merupakan model yang sistematik, karena semua tahapan harus dilalui. Model ini dapat dilihat pada gambar 1. Tahapan Analysis merupakan tahap awal yang dilakukan dalam proses pengembangan, pada tahapan ini dilakukan analisis kebutuhan pengguna dan kebutuhan hardware dan software. Dalam hal ini, kebutuhan pengguna adalah alat evaluasi kognitif berbasis android, karena alat evaluasi ini tersebut belum tersedia. 
Selanjutnya tahapan Design dilakukan sesuai dengan hasil analisis kebutuhan. Pada tahap ini pengembang membuat flowchart dan design interface aplikasi. Tahap Development adalah tahapan pembuatan produk yang telah diseuaikan dengan tahapan design dengan menggunakan software android studio. Tahapan Implementation adalah menerapkan aplikasi yang telah dibuat kepada pengguna. Pengguna disini adalah mahasiswa Program Studi Pendidikan Teknologi Informasi IKIP PGRI Pontianak Tahapan terakhir adalah Evaluation, tahapan ini bertujuan untuk melihat keefektifan produk yang telah dikembangkan.

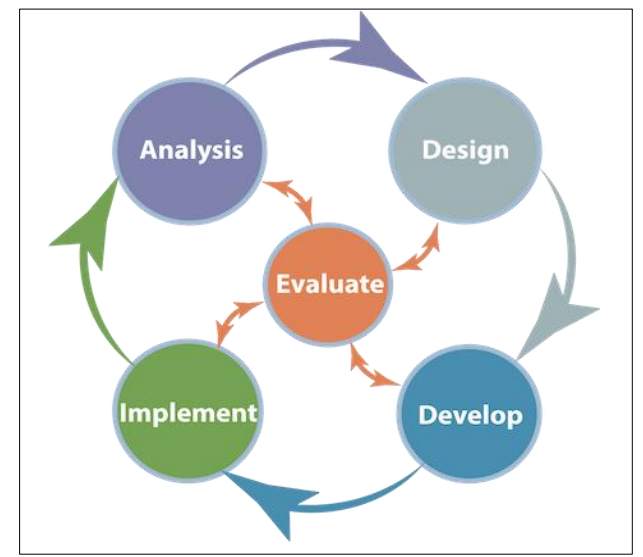

Gambar 1. Model Pengembangan ADDIE (Harjanta \& Herlambang, 2018)

Subjek dalam penelitian ini terbagi dua, yakni subjek pengembangan dan subjek uji coba produk. Subjek pengembangan adalah ahli media yang bertujuan untuk menguji kelayakan alat evaluasi kognitif berbasis android. Dan subjek uji coba produk adalah mahasiswa Program Studi Pendidikan Teknologi Informasi IKIP PGRI Pontianak Subjek uji coba di bagi dua, yakni uji coba skala kecil yang melibatkan 10 mahasiswa. Dan uji coba skala besar yang melibatkan 42 mahasiswa.

Teknik pengumpulan data yang digunakan adalah dengan menggunakan angket tertutup dengan empat alternatif jawaban. Data yang terkumpul dianalisis dengan teknis analisis deskriptif kuantitatif. Data akan disajikan dalam bentuk skor dan persentase. Persentase kelayakan hasil uji coba produk dapat dilihat pada persamaan 1.

$$
\text { Persentase kelayakan }(\%)=\frac{\text { Skor yang di dapat }}{\text { Skoryang diharapkan }} \times 100 \%
$$

Tabel 1. Kategori Pencapaian Kelayakan

\begin{tabular}{ccc}
\hline No & Persentase Pencapaian & Klasifikasi Kelayakan \\
\hline $\mathbf{1}$ & $81 \%-100 \%$ & Sangat Layak \\
$\mathbf{2}$ & $61 \%-80 \%$ & Layak \\
$\mathbf{3}$ & $41 \%-60 \%$ & Cukup Layak \\
$\mathbf{4}$ & $21 \%-40 \%$ & Kurang Layak \\
$\mathbf{5}$ & $0 \%-20 \%$ & Tidak layak \\
\hline
\end{tabular}

Arikunto dalam (Amna et al., 2018)

\section{HASIL DAN PEMBAHASAN \\ Hasil}

Pengembangan alat evaluasi kognitif berbasis android ini dibuat sebagai media yang digunakan dalam meng-evaluasi hasil pembelajaran yang telah dilakukan dikelas. Berbasis android karena sistem operasi android merupakan salah satu yang banyak digunakan oleh mahasiswa di IKIP PGRI Pontianak. Berdasarkan tahapan pengembangan ADDIE, pada tahapan pertama yakni analisis, telah didapatkan kebutuhan pengguna yakni berupa alat 
evaluasi kognitif berbasis android. Selanjutnya pada tahapan design, pengembangan alat evaluasi ini memiliki rancangan yang dapat dilihat pada gambar 1. Flowchart yang terlihat pada gambar 3 digunakan untuk memberikan gambaran alur kerja aplikasi yang dibuat. Selain itu, pada tahapan ini dibuat juga desain interface aplikasi.

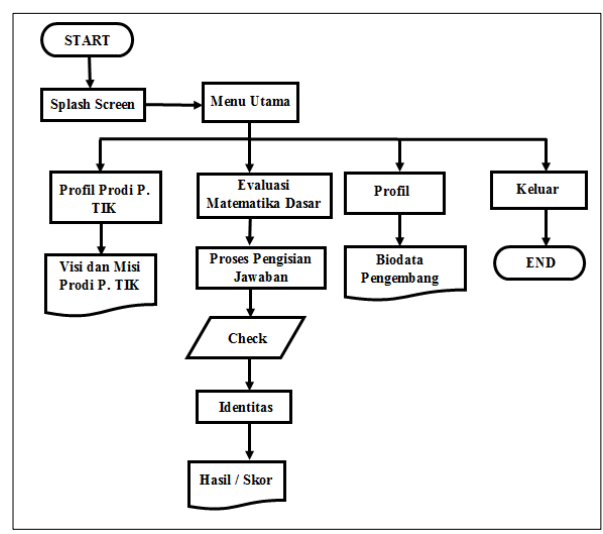

Gambar 2. Flowchart Aplikasi Alat Evaluasi Kognitif

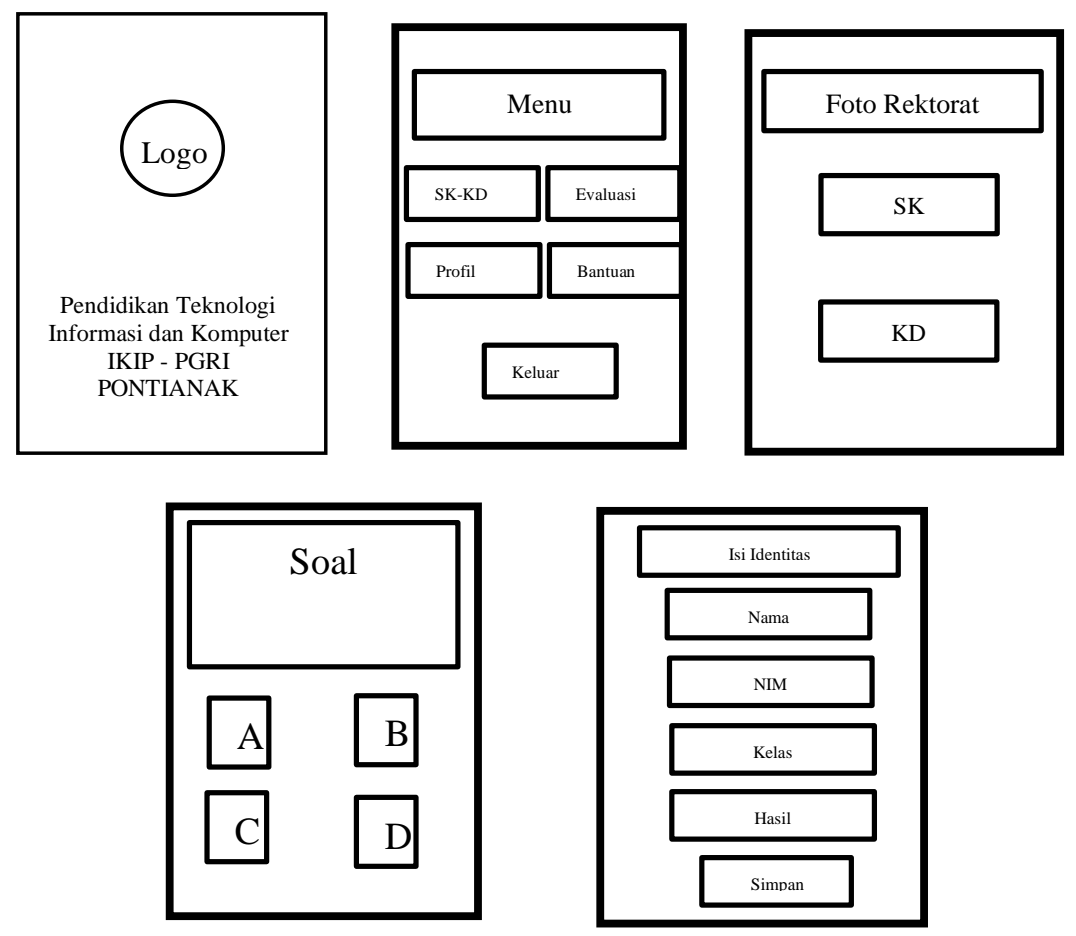

Gambar 3. Design Interface

Selanjutnya tahapan development, tahapan ini merupakan tahapan pembuatan aplikasi dengan menggunakan aplikasi APP Inventor. Pada tahapan ini, produk sudah dibuat dan siap untuk di ujicobakan kepada pengguna. Berikut adalah gambaran user interface (tampilan antar muka) dari aplikasi yang telah dibuat pada tahapan development. Tampilan user interface dapat dilihat pada gambar 4. Pada gambar 4 tersebut, terdapat lima interface aplikasi yang di tampilkan. Interface tersebut memperlihatkan tampilan awal (home) aplikasi, tampilan menu yang terdapat di aplikasi, lalu SK-KD yang berfungsi untuk menjelaskan Standar Kompetensi-Kompetensi Dasar dari pembelajaran yang di sampaikan. Selanjutnya tampilan soal evaluasi yang berbetuk pilihan ganda dan terakhir adalah tampilan untuk mengisi identitas diri dan tampilan hasil yang diperoleh dari evaluasi yang teah dilaksanakan. 

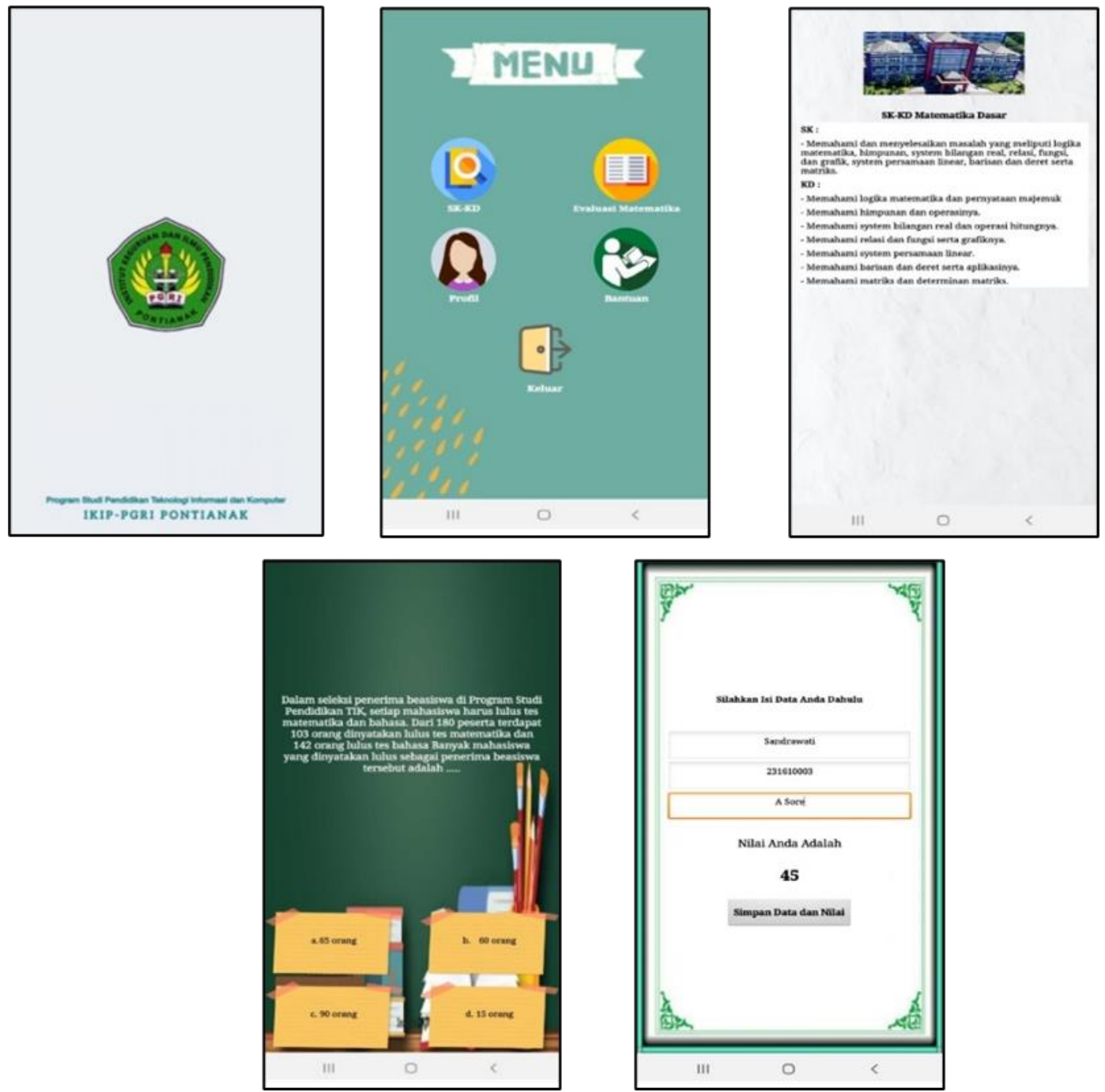

Gambar 4. User Interface Aplikasi

Hasil design dan development divalidasi oleh 3 orang ahli media. Validasi ini dilakukan untuk melihat kelayakan aplikasi untuk diujicobakan kepada pengguna. Terdapat 3 aspek yang divalidasi oleh ahli media. Pertama adalah aspek umum yang berisi mengenai konten yang terdapat dalam aplikasi yang dikembangkan. Kedua adalah aspek rekayasa perangkat lunak yang berisi efektifitas, efisiensi, reliabilitas dan usabilitas aplikasi. Dan terakhir adalah aspek komunikasi visual yang berisi tampilan dan layout interactive yang ada dalam aplikasi. Hasil validasi ahli media dapat dilihat dalam tabel 2.

Tabel 2. Hasil Validasi Ahli Media

\begin{tabular}{cccccccc}
\hline \multirow{2}{*}{ No } & \multirow{2}{*}{ Aspek } & \multicolumn{3}{c}{ Nilai Ahli Media } & \multirow{2}{*}{ Total } & \multirow{2}{*}{$*$} & \multirow{2}{*}{ Kategori } \\
\hline $\mathbf{1}$ & & $\mathbf{1}$ & $\mathbf{2}$ & $\mathbf{3}$ & & & \\
$\mathbf{2}$ & Umum & 22 & 22 & 21 & 65 & $90 \%$ & Sangat Layak \\
$\mathbf{3}$ & Rekayasa Peraangkat Lunak & 25 & 27 & 23 & 75 & $89 \%$ & Sangat Layak \\
& Komunikasi Visual & 29 & 30 & 29 & 88 & $92 \%$ & Sangat Layak \\
& Skor Total & 76 & 79 & 73 & 228 & $90,3 \%$ & Sangat Layak \\
\hline
\end{tabular}

Pada tahap implementasi, aplikasi ini di ujicobakan kepada 10 orang sebagai subjek uji coba skala kecil. Hal ini dilakukan untuk melihat dan menguji apakah aplikasi ini layak atau 
tidak digunakan dan diimplementasikan ke skala lebih besar. Dalam uji coba ini, responden diberikan angket untuk memberikan respon mengenai aplikasi yang telah dibuat. Terdapat 4 aspek yang dinilai, 3 aspek pertama sama dengan yang diberikan kepada ahli media yakni aspek umum, rekayasa perangkat lunak dan komunikasi visual. Sedangkan aspek keempat adalah aspek kualitas instruksional yang berisi instruksi yang dibutuhkan oleh pengguna dalam penggunaan aplikasi. Hasil lebih detailnya yang didapat dapat dilihat dalam tabel 3 .

Tabel 3. Hasil Uji Coba Skala Kecil

\begin{tabular}{ccccc}
\hline No & Aspek & Skor Yang Diperoleh & \% & Kategori \\
\hline $\mathbf{1}$ & Umum & 119 & $74 \%$ & Layak \\
$\mathbf{2}$ & Rekayasa Peraangkat Lunak & 154 & $77 \%$ & Layak \\
$\mathbf{3}$ & Komunikasi Visual & 218 & $78 \%$ & Layak \\
$\mathbf{4}$ & Kualitas Intruksional & 117 & $73 \%$ & Layak \\
& Skor & 608 & $76 \%$ & Layak \\
\hline
\end{tabular}

Selanjutnya, dilakukan implementasi pada skala yang lebih besar. Pada tahapan ini melibatkan 42 orang mahasiswa sebagai subjek implementasi produk. Pada implentasi ini, responden diberikan angket respon untuk menilai mengenai kegunaan aplikasi yang telah di buat. Aspek yang dinilai sama dengan pada saat uji coba produk skala kecil. Hasil yang didapat dapat dilihat pada tabel 4.

Tabel 4. Hasil Uji Coba Skala Besar

\begin{tabular}{clccc}
\hline No & Aspek & Skor yang Diperoleh & Persentase(\%) & Kategori \\
\hline $\mathbf{1}$ & Umum & 526 & $78 \%$ & Layak \\
$\mathbf{2}$ & Rekayasa & 675 & $80 \%$ & Sangat Layak \\
& Peraangkat Lunak & 968 & & \\
$\mathbf{3}$ & Komunikasi Visual & 546 & $82 \%$ & Sangat Layak \\
$\mathbf{4}$ & Kualitas & & $81 \%$ & Sangat Layak \\
& Intruksional & & & \\
$\quad$ Skor & 2715 & $81 \%$ & Sangat Layak \\
\hline
\end{tabular}

\section{Pembahasan}

Aplikasi yang telah dikembangkan ini digunakan untuk membantu dosen dalam melakukan evaluasi pembelajaran supaya lebih mudah dan efisien. Dalam proses pengembangannya, aplikasi ini dikembangkan dengan mengunakan model ADDIE. Aplikasi divalidasi oleh ahli media untuk menilai dan melihat apakah aplikasi sudah layak atau belum untuk diterapkan. Berdasarkan hasil validasi ahli media yang melibatkan 3 orang, rata - rata persentase kelayakan yang diperoleh adalah $90,3 \%$. Hal ini menunjukan bahwa aplikasi ini Sangat Layak untuk di terapkan. Namun aplikasi ini masih perlu diperbaiki mengikuti saran dari ahli media.

Selanjutnya aplikasi ini diuji cobakan di skala kecil, dan hasil yang diperoleh adalah $76 \%$ yang menunjukan bahwa aplikasi ini Layak untuk digunakan. Berdasarkan hasil validasi oleh ahli media dan juga uji coba skala kecil, maka aplikasi ini diterapkan dan melibatkan 42 orang mahasiswa sebagai subjek implementasi dari aplikasi. Berdasarkan hasil implementasi, didapatkan hasil bahwa berdasarkan aspek umum aplikasi ini memperoleh skor 78\%, sedangkan untuk aspek rekayasa perangkat lunak meperoleh skor $80 \%$. Untuk aspek komunikasi visual memperoleh skor $82 \%$ dan aspek kualitas instruksional memperoleh skor $81 \%$. Dan rata - rata skor yang diperoleh adalah $81 \%$, angka ini menunjukan bahwa aplikasi yang telah dibuat sangat layak untuk digunakan. Berdasarkan hasil respon yang telah 
diberikan, dapat dilihat bahwa dari keempat aspek yang ada, secara keseluruhan mencapai skor yang tinggi. Hal ini menunjukan bahwa respon yang diberikan oleh pengguna sudah sangat baik. Karena aspek - aspek dalam pengembangan aplikasi telah terpenuhi dengan baik. Maka dapat disimpulkan bahwa aplikasi yang dibuat sangat layak untuk digunakan sebagai alat evaluasi kognitif dalam proses pembelajaran di Program Studi PTIK IKIP PGRI Pontianak.

Pemanfaatan alat evaluasi kognitif berbasis android ini sangat membantu dosen pada proses akhir pembelajaran. Dengan aplikasi ini, dosen akan menghemat waktu dan tenaga dalam melakukan pemeriksaan soal dan perekapan nilai akhir dari setiap mahasiswa (Sujarwinanti et al., 2020). Karena proses penilaian dan perekapan nilai sudah dibuat secara otomatis di dalam aplikasi. Setelah selesai melakukan proses evaluasi, maka nilai akan langsung bisa dilihat oleh maahasiswa dan masuk ke dalam data nilai mahasiswa. Pernyataan ini dipertegas oleh hasil penelitian yang telah dilakukan oleh (Olisca \& Achadiyah, 2014) yang menunjukan bahwa kelebihan potensi ujian online adalah pelaporan skor langsung, penurunan beban biaya administrasi, peningkatan keamanan bahan pengujian, dan penjadwalan ujian yang lebih fleksibel. Selain itu, Fajriyyah \& Nugrahalia (2021) dalam penelitiannya menjelaskan bahwa aplikasi evaluasi kognitif lebih efektif dibandingkan dengan kertas dan pena. Pernyataan tersebut mempertegas hasil penelitian yang telah dilakukan. Karena dengan memanfaatkan aplikasi ini, dosen tidak perlu menggandakan soal dan juga tidak memerlukan waktu lebih dalam menggoreksi hasil evaluasi. Selain itu, respon yang didapat dari mahasiwa uji coba skala besar cukup baik. Karena bagi mahasiswa, evaluasi pembelajaran dengan menggunakan aplikasi ini menjadi lebih menarik. Karena sebelumnya mahasiswa belum pernah melakukan evaluasi dengan menggunakan sebuah aplikasi. Selain itu juga alat aveluasi ini dapat memotivasi mahasiwa untuk belajar lebih giat lagi. (Daryanes \& Ririen, 2020) menjelaskan bahwa, pemanfaatan aplikasi dalam evaluasi sangat efektif untuk meningkatkan motivasi mahasiswa. Hal ini dikarenakan hasil evaluasi langsung dipaparkan kepada mahasiswa. Sejalan dengan pernyataan tersebut, dalam penelitian yang dilakukan oleh Irwan et al., (2019) dijelaskan bahwa penggunaan aplikasi dalam proses evaluasi pembelajaran cukup efektif.

Sejalan dengan penelitian-penelitian yang telah dilakukan sebelumnya, yang menunjukan bahwa evaluasi pembelajaran menggunakan aplikasi sangatlah efektif dan efisien baik dalam menghemat waktu dan tenaga. Hasil penelitian ini juga menunjukan hal yang serupa. Hal ini dapat dilihat dari hasil validasi yang diperoleh dan juga dari tingginya respon yang diberikan oleh pengguna. Selain itu juga, fungsi dari aplikasi yang telah di buat ini sudah sesuai dengan tujuan yang diinginkan. Maka dapat disimpulkan bahwa dengan memanfaatkan teknologi berupa aplikasi berbasis android, maka proses pelaksanaan evaluasi kognitif akan lebih mudah dan efisien.

\section{SIMPULAN}

Penelitian ini telah berhasil mengembangkan aplikasi sebagai alat evaluasi kognitif berbasis android di Program Studi Pendidikan Teknologi Informasi dan Komputer (PTIK) IKIP PGRI Pontianak. Pengembangan ini merupakan salah satu bentuk dari pemanfaatan teknologi di bidang Pendidikan. Dari hasil penelitian dapat disimpulkan bahwa aplikasi ini sangat layak untuk digunakan. Berdasarkan uji kelayakan yang telah dilakukan, menunjukan bahwa aplikasi ini sangat layak untuk digunakan. Selain itu berdasarkan hasil implementasi kepada 42 mahasiswa, dinyatakan bahwa aplikasi ini sangat layak untuk digunakan, dan juga mendapatkan hasil respon yang sangat baik. Karena aplikasi telah memenuhi aspek - aspek yang dibutuhkan dalam pengembangan sebuah aplikasi. Dengan adanya aplikasi sebagai alat evaluasi kognitif, maka proses evaluasi dapat dilakukan dengan lebih mudah, efektif dan juga 
efisien. Karena dapat menghemat biaya dan juga waktu baik bagi mahasiswa ataupun bagi dosen.

\section{REFERENSI}

Amna, M., Wirasasmita, R. H., \& Fathoni, A. (2018). Pengembangan Media Pembelajaran Berbasis Android Pada Mata Kuliah Sistem Operasi di Universitas Hamzanwadi. EDUMATIC: Jurnal Pendidikan Informatika, 2(1), 1-7. https://doi.org/10.29408/edumatic.v2i1.816

Cholik, C. A. (2017). Pemanfaatan Teknologi Informasi dan Komunikasi Untuk meningkatkan Pendidikan Indonesia. Syntax Literate, 6(6), 5-9.

Daryanes, F., \& Ririen, D. (2020). Efektivitas Penggunaan Aplikasi Kahoot Sebagai Alat Evaluasi pada Mahasiswa. Journal of Natural Science and Integration, 3(2), 172-186. https://doi.org/10.24014/jnsi.v3i2.9283

Fajriyyah, A., \& Nugrahalia, M. (2021). Efektivitas Aplikasi Kahoot! Sebagai Alat Evaluasi Kognitif Pada Materi Sistem Pencernaan Manusia. Jurnal Pelita Pendidikan, 4(4), 224 229.

Harjanta, A. T. J., \& Herlambang, B. A. (2018). Rancang Bangun Game Edukasi Pemilihan Gubernur Jateng Berbasis Android Dengan Model ADDIE. Jurnal Transformatika, 16(1), 91-97. https://doi.org/10.26623/transformatika.v16i1.894

Irwan, I., Luthfi, Z. F., \& Waldi, A. (2019). Efektifitas Penggunaan Kahoot! untuk Meningkatkan Hasil Belajar Siswa. Pedagogia: Jurnal Pendidikan, 8(1), 95-104. https://doi.org/10.21070/pedagogia.v8i1.1866

Kuswanto, J., \& Radiansah, F. (2018). Media Pembelajaran Berbasis Android Pada Mata Pelajaran Sistem Operasi Jaringan Kelas XI. Jurnal Media Infotama, 14(1), 15-20. https://doi.org/10.37676/jmi.v14i1.467

Mahirah, B. (2017). Evaluasi Belajar Peserta Didik (Siswa). Idaarah: Jurnal Manajemen Pendidikan, 1(2), 257-267. https://doi.org/10.24252/idaarah.v1i2.4269

Matsun, M., Ramadhani, D., \& Lestari, I. (2018). Pengembangan Bahan Ajar Listrik Magnet Berbasis Android Di Program Studi Pendidikan. Jurnal Pendidikan Matematika Dan IPA, 9(1), 99-107.

Nurbudiyani, I. (2013). Pelaksanaan Pengukuran Ranah Kognitif, Afektif, dan Psikomotorik pada Mata pelajaran IPS di Kelas III SD Muhammadiyah Palangkaraya. Journal Tunas Bangsa, 13(1), 88-93.

Nuriyah, N. (2014). Evaluasi pembelajaran: Sebuah Kajian Teori. Jurnal Edueksos, 3(1), 7386. https://doi.org/10.1165/rcmb.2013-04110C

Olisca, R. U. C., \& Achadiyah, B. N. (2014). Pengembangan Media Evaluasi Pembelajaran Dalam Bentuk Online Berbasis E-Learning Menggunakan Software Wondershare Quiz Creator Dalam Mata Pelajaran Akuntansi Sma Brawijaya Smart School (Bss). Jurnal Pendidikan Akuntansi Indonesia, 12(2), 41-48. https://doi.org/10.21831/jpai.v12i2.2706

Putra, R. S., Wijayati, N., \& Widhi, F. (2017). Pengaruh Penggunaan Media Pembelajaran Berbasis Aplikasi Android Terhadap Hasil Belajar Siswa. Jurnal Inovasi Pendidikan Kimia, 11(2), 2009-2018.

Rahmayanti, I., \& Wibowo, A. (2019). Keseuaian Alat Evaluasi dengan Aspek Kognitif pada Buku Teks Bahasa Indonesia Kelas XI SMA Kurikulum 2013 Edisi Revisi 2016 Terbitan Yrama Widya (Analasis Isi). Prosiding Seminar Nasional Pascasarjana (Prosnampas), 2(1), 714-724.

Setemen, K. (2010). Pengembangan Evaluasi Pembelajaran Online. Jurnal Pendidikan Dan Pengajaran, 43(3), 207-214.

Setyawardani, D., Rusilowati, A., \& Hartanto. (2012). Pengembangan Alat Evaluasi Proposition Generating Task untuk Mengukur Struktur Kognitif Siswa di SMA. Journal 
of Innovative Science Education, 1(2), 85-91.

Sujarwinanti, S., Ma'rufi, M., \& Al'anshori, F. (2020). Pengembangan Alat Evaluasi Berbasis Aplikasi Android pada Pokok Bahasan Sistem Ekskresi di SMPN 2 Bua. Journal of Innovative Science Education, 5(1), 33-49. 